\title{
Decreased Natural and Antibody-Dependent Cellular Cytotoxic Activities in Intravenous Drug Abusers ${ }^{1}$
}

\author{
Madhavan P. N. Nair, ${ }^{2}$ Timothy J. Laing, and Stanley A. Schwartz 3 \\ Departments of Pediatrics, Epidemiology and Internal Medicine. The University of Michigan. \\ Ann Arbor. Michigan 48109
}

\begin{abstract}
Peripheral blood lymphocytes from 14 adult male patients admitted to the hospital with complications of intravenous drug abuse (IDA) were examined for natural killer (NK) and antibody-dependent cellular cytotoxic (ADCC) activities. lectin-dependent cellular cytotoxicity, and interferon (IFN)-and interleukin 2 (IL-2)-induced NK activity. Serum was also assayed for circulating interferon levels and soluble factor(s) capable of suppressing the cytotoxic potential of allogeneic lymphocytes from healthy donors. IDA patients demonstrated significantly decreased levels of NK and ADCC activities compared to age- and sex-matched healthy controls. The lectin, phytohemagglutinin, could significantly enhance the cytotoxicity of IDA lymphocytes: however. activity was not completely restored to normal levels. IDA sera demonstrated a significant inhibitory effect on the NK and ADCC activities of normal allogeneic lymphocytes. and these sera contained negligible levels of circulating IFN. Although the NK activity of IDA Iymphocytes could not be restored completely to normal levels by either IFN- $\alpha$ or IL.-2. the percentage enhancement of cytotoxicity was remarkably higher in IDA patients with significantly reduced NK activity than that observed using PBL from patients with near normal NK activity. The ability of IFN or IL-2 to enhance the decreased cytotoxicity of PBL from drug abusers suggests a novel therapeutic approach to the management of the complications of IDA. 1986 Academic Press. Inc.
\end{abstract}

\section{INTRODUCTION}

The principal victims of acquired immunodeficiency syndrome (AIDS) have been male homosexuals, Haitian immigrants, hemophiliacs, and drug abusers (114). AIDS is characterized by profound deficiency of cell-mediated immune responses and selective abnormalities of immunoregulation $(2,5,6,11,12,15-17)$. Many similar immunologic abnormalities such as hypergammaglobulinemia, diffuse hyperplasia of lymphoid tissues, smooth muscle and lymphotoxic antibodies. reduced number of active rosette-forming $\mathrm{T}$ cells, marked depression of the lymphoproliferative response to antigens and mitogens, alteration of $\mathrm{T}$-lymphocyte subsets, cutaneous anergy, increased incidence of malignancy, lymphopenia, etc. have been observed in patients with narcotic addiction (18-24). The current investigations were undertaken to determine the effect of prolonged abuse of intra-

${ }^{1}$ This work was aided by National lnstitutes of Health Grants CA 35922 and Al 19890. the Children's Leukemia Foundation of Michigan. and the Michigan Diabetes Research and Training Center. University of Michigan.

2 To whom reprint requests should be addressed: The University of Michigan, Department of Pediatrics, School of Public Health-I, Ann Arbor, Mich. 48109.

${ }^{3}$ Recipient of NIH Research Career Development Award CA 00896. 
venous drugs on NK and ADCC functions of lymphocytes. These studies demonstrate that peripheral blood lymphocytes of patients with a history of intravenous drug abuse (IDA) display significantly lower NK and ADCC activities than healthy age- and sex-matched control donors.

\section{METHODS}

Patients. Fourteen male patients ranging from 25 to 45 years old were selected from the Outpatient Clinics of the Wayne County (Mich.) General Hospital which serves portions of the greater Detroit metropolitan area. In addition to the intravenous use of heroin, pentazocine $\mathrm{HCl}$ plus pyribenzamine, hydromorphone $\mathrm{HCl}$, and cocaine, these patients often had a history of the abuse of other substances taken orally including: marijuana, various tranquilizers, amphetamines, hallucinogens, and ethanol alone or in combinations. Because of extensive and indiscriminate drug usage, it is not possible to accurately tabulate the drug repertoire for any individual subject. The duration of drug abuse ranged from 2 to 17 years with an average of 12.5 years. Drug consumption persisted during the study period. As controls, 7 healthy age- and sex-matched volunteers were recruited from the students and staff of The University of Michigan. Peripheral blood from patients and healthy donors was drawn into a plastic syringe containing heparin (20 $\mathrm{U} / \mathrm{ml}$ ). Donors were apprised of the study and consents were obtained consistent with the policies of The University of Michigan and the National Institutes of Health. Confidentiality was maintained by using only coded designations.

Isolation of lymphocytes. Peripheral blood mononuclear cells (PBMC) were isolated from heparinized venous blood on a Ficoll-Hypaque gradient using a modified method of Boyum (25). Blood was diluted with an equal volume of normal saline $(0.85 \%)$ and centrifuged at $400 \mathrm{~g}$ for $30 \mathrm{~min}$ at $18^{\circ} \mathrm{C}$. The mononuclear cell band was harvested, washed three times with saline, and resuspended in RPMI 1640 medium containing $25 \mathrm{~m} M$ Hepes buffer, $80 \mu \mathrm{g} / \mathrm{ml}$ gentamicin (Schering Corp., Kenilworth, N.J.), $300 \mu \mathrm{g}$ fresh glutamine per ml and 10\% FCS (complete medium). The viability of the cells was routinely greater than $98 \%$ as assessed by trypan blue dye exclusion.

Removal of adherent cells. PBMC were suspended in complete medium and passed through a 7-ml column of Sephadex G-10 beads (Pharmacia Fine Chemicals, Piscataway, N.J.) equilibrated with the same medium to deplete adherent cells. After $45 \mathrm{~min}$ of incubation at $37^{\circ} \mathrm{C}$, nonadherent cells (PBL) were washed through with one bed volume of medium at $37^{\circ} \mathrm{C}$. PBL were washed three times with RPMI 1640 medium and suspended in complete medium. Viability was always greater than $95 \%$ as assessed by trypan blue dye exclusion.

Preparation of tumor target cells. The human erythroleukemia cell line, K-562, was used as targets for NK cells. For the ADCC assay, we chose as targets an antibody-coated human B-cell leukemia line (SB) because of resistance to NK activity in a $4 \mathrm{hr}{ }^{51} \mathrm{Cr}$ release assay. Tumor target cells were serially passaged in complete medium and used in cytotoxicity assays no more than $48 \mathrm{hr}$ after the last passage. To $0.8-\mathrm{ml}$ aliquots of complete medium containing $5 \times 10^{6}$ washed tumor cells, $200 \mu \mathrm{Ci}$ of ${ }^{51} \mathrm{Cr}$ as sodium chromate (New England Nuclear, Boston, Mass.) was added. The cells were incubated at $37^{\circ} \mathrm{C}$ for $1 \mathrm{hr}$ in a humidified 
atmosphere of $5 \% \mathrm{CO}_{2}$ in air, with intermittent shaking. After incubation the cells were washed three times with complete medium and resuspended to a concentration of $2 \times 10^{5}$ cells $/ \mathrm{ml}$.

Assay for NK activity. NK activity was measured in a direct ${ }^{51} \mathrm{Cr}$ release assay as previously described $(26,27)$. A fixed number of viable effector PBL in complete medium was added to triplicate cultures of ${ }^{51} \mathrm{Cr}$-labeled targets in $\mathrm{V}$-bottom microtitration plates (CoStar, Cambridge, Mass.). After centrifugation at $40 \mathrm{~g}$ for $2 \mathrm{~min}$, they were incubated at $37^{\circ} \mathrm{C}$ in a humidified atmosphere of $5 \% \mathrm{CO}_{2}$ in air, for $4 \mathrm{hr}$. At the end of incubation, the plates were centrifuged at $400 \mathrm{~g}$ for $10 \mathrm{~min}$ and $100-\mu l$ quantities of supernates were removed from each well and counted in a Packard Model 593 gamma counter. Percentage cytotoxicity was calculated as:

$$
\% \text { cytotoxicity }=\frac{\text { experimental release }- \text { spontaneous release }}{\text { total release }- \text { spontaneous release }} \times 100 \text {, }
$$

where spontaneous release represents counts released from control wells containing only $2 \times 10^{4}$ target cells, and total release represents counts obtained from an aliquot of $2 \times 10^{4}$ target cells.

Assay for ADCC. ADCC activity was determined as previously described (26, 27). Briefly, $50 \mu \mathrm{l}$ of varying concentrations of effector cells were added to $50 \mu \mathrm{l}$ of complete medium containing ${ }^{51} \mathrm{Cr}$-labeled SB target cells and $100 \mu \mathrm{l}$ of a $2 \times$ $10^{-4}$ dilution of rabbit anti-SB antisera previously found to yield maximum ADCC: Percentage ADCC was calculated as described above for NK activity with the following exceptions. Spontaneous release represents counts released in control wells containing effector cells, labeled SB target cells. and media instead of anti-SB antibodies, and total release represents counts obtained in an aliquot of $1 \times 10^{4}{ }^{51} \mathrm{Cr}$-labeled SB target cells. The spontaneous release of target cells in the presence of anti-target antibodies without effectors was similar to the spontaneous release of target cells in the presence of effector cells and media alone.

Lectin-dependent cell-mediated cytotoxicity ( $L D C C$ ) assay. The LDCC assay was carried out similar to the NK assay. Briefly, appropriate numbers of target and effector cells were added in V-bottom microtitration plates and various concentrations of phytohemagglutinin-P (Difco Laboratories. Detroit. Mich.) 1. 2.5. and $5 \mu \mathrm{g} / \mathrm{ml}$, were added to a final volume of $0.2 \mathrm{ml}$ and incubated for $4 \mathrm{hr}$ at $37^{\circ} \mathrm{C}$ in a humidified $5 \% \mathrm{CO}_{2} / 95 \%$ air incubator. Percentage LDCC activity was calculated as described for the NK activity and was compared with cytotoxicity observed with control culltures containing effector and target cells. Percentage cytotoxicity was calculated as:

$$
\% \text { cytotoxicity }=\frac{\text { experimental release }- \text { spontaneous release }}{\text { total release }- \text { spontaneous release }} \times 100 \text {. }
$$

where spontaneous release represents counts released from control wells containing $2 \times 10^{4}$ target cells plus lectin and total release represents counts obtained from $2 \times 10^{4}$ lysed target cells.

Treatment of effector cells with sera. Both control and patients' sera were heat inactivated in a $56^{\circ} \mathrm{C}$ water bath for $30 \mathrm{~min}$ and centrifuged at $10,000 \mathrm{~g}$ for $1 \mathrm{hr}$. 
The supernates were collected and used in the NK and ADCC assays. All sera were tested in the assays within a week of collection. To test the inhibition of cytotoxic effector cell functions by sera, $5 \times 10^{5}$ cells $/ \mathrm{ml}$ of complete medium werc incubated scparatcly with cither control or patients' scrum at a final concentration of $10 \%(\mathrm{~V} / \mathrm{V})$ for $24 \mathrm{hr}$ in a $5 \% \mathrm{CO}_{2} / 95 \%$ air incubator, washed, and tested for cytotoxicity. Viability of serum treated samples after incubation was always greater than $90 \%$. Percentage cytotoxicity was calculated as described above for the NK assay.

Interferon (IFN). Partially purified human leukocyte IFN- $\alpha$ was obtained as a gift from Parke-Davis and Company (Detroit, Mich.). The sp act was $6.3 \times 10^{4}$ $\mathrm{U} / \mathrm{mg}$ protein. IFN was diluted in RPMI 1640 medium and stored at $-70^{\circ} \mathrm{C}$ before use.

Interleukin 2 (IL-2). Commercially available IL-2 (Electro-Nucleonics Labs, Inc., Silver Spring, Md.) was diluted in RPMI 1640 and stored at $-70^{\circ} \mathrm{C}$ before use. IL-2 was purified from human peripheral blood leukocytes by several chromatographic steps and is devoid of any lectin or IFN. The maximum NK augmenting dose (10\% final concentration) as previously determined, was used.

Treatment of effector cells with IFN or $I L-2$. PBL $\left(2 \times 10^{6} / \mathrm{ml}\right)$ were washed and suspended in $1 \mathrm{ml}$ of RPMI $1640+5 \%$ FCS to which $500 \mathrm{U}$ of IFN- $\alpha$ or $10 \%(\mathrm{~V} / \mathrm{V})$ IL-2 previously found to yield maximal $\mathrm{NK}$ augmenting effect was added. The cultures were incubated for $24 \mathrm{hr}$ at $37^{\circ} \mathrm{C}$ in a humidified atmosphere of $5 \% \mathrm{CO}_{2}$ in air, washed twice, and resuspended in medium. Control cultures were treated identically with the exception that either IFN or IL-2 was not added. Viability of treated lymphocytes was unaffected as assessed by trypan blue dye exclusion. Both treated and control cultures were assayed for NK activity.

\section{RESULTS}

Lymphocytes from IDA patients and healthy adults were tested against ${ }^{51} \mathrm{Cr}$ labeled K562 target cells in the NK assay and antibody-coated SB targets in the ADCC assay at effector to target (E:T) cell ratios varying from 100:1 to 5:1. (Tables 1 and 2). PBL from IDA patients displayed significantly decreased NK and $\mathrm{ADCC}$ activities against $\mathrm{K} 562$ and $\mathrm{SB}$ targets respectively, at all E:T cell ratios, compared to lymphocytes from age- and sex-matched healthy volunteers.

Since IDA lymphocytes demonstrated reduced NK and ADCC activities, we examined whether IDA lymphocytes could be activated by lectin. The data prsented in Table 3 demonstrate that control lymphocytes at an E:T cell ratio of 50:1 produced $29.3(P<0.005)$ and $25.7 \%(P<0.005)$ LDCC activity against SB targets at 1 and $2.5 \mu \mathrm{g} / \mathrm{ml}$ of PHA, respectively, compared to $4.2 \%$ cytotoxicity observed in the absence of PHA. PBL from IDA patients showed $3 \%$ cytotoxicity without PHA which was significantly enhanced to $15.7(P<0.005)$ and $15.9 \%(I$ $<0.01$ ) by PHA at 1 and $2.5 \mu \mathrm{g} / \mathrm{ml}$ concentrations, respectively. Lectin at an increased concentration of $5 \mu \mathrm{g} / \mathrm{ml}$ also resulted in increased cytotoxicity by both control $(19.7 \%)(P<0.005)$ and IDA lymphocytes $(14 \%)(P<0.05)$. Although PHA addition could considerably enhance the cytotoxicity of IDA lymphocytes, activity was not completely restored to levels shown by control lymphocytes. 
TABLE 1

NK ACTIVITy of Lymphocytes from Healthy DONORS and InTRavenols Drlg Abusers a Varying EFFector to Target Cfll Ratios

\begin{tabular}{|c|c|c|c|c|c|}
\hline \multirow[b]{3}{*}{ Expl } & \multirow{3}{*}{$\begin{array}{l}\text { Lymphocyte } \\
\text { source }\end{array}$} & \multicolumn{4}{|c|}{ E:T cell ratios } \\
\hline & & 100:1 & $50: 1$ & $25: 1$ & $5: 1$ \\
\hline & & \multicolumn{4}{|c|}{ Cylotoxicity $(C)$} \\
\hline \multirow{2}{*}{1} & Controls & $42.8 \pm 3.8$ & $36.9 \pm 5.6$ & $23.8 \pm 3.1$ & $10.2 \pm 1.2$ \\
\hline & IDA & $31.5 \pm 8.2$ & $26.5 \pm 9.8$ & $14.3+6.2$ & $5.5 \pm 2.4$ \\
\hline \multirow{2}{*}{2} & Controls & $53.4 \pm 8.2$ & $43.3 \pm 7.2$ & $25.3=3.1$ & $15.4 \pm 2.1$ \\
\hline & IDA & $29.6 \pm 5.9$ & $25.3 \pm 6.3$ & $13.4 \pm 1.9$ & $8.7=0.7$ \\
\hline \multirow{2}{*}{3} & Controls & $48.1 \pm 5.6$ & $32.1 \pm 4.1$ & $25.2=5.2$ & $18.6 \pm 4.6$ \\
\hline & IDA & $25.5 \pm 7.8$ & $23.1 \pm 8.2$ & $17.5 \pm 6.5$ & $7.5+3.8$ \\
\hline \multirow{3}{*}{4} & Controls" & $52.4 \pm 7.1$ & $47.8 \pm 4.9$ & $32.3+4.6$ & $20.2 \pm 3.2$ \\
\hline & IDA & $18.6 \pm 1.0$ & $14.3 \pm 1.2$ & $12.1 \pm 0.4$ & $x .2 \div 3.1$ \\
\hline & & $P<0.005$ & $P<0.004$ & $P<11.006$ & $P<0.0016$ \\
\hline
\end{tabular}

"Effector cells were depleted of phagocytic cells. by passage through a G-10 column. K562 target cells were labeled with ${ }^{51} \mathrm{Cr}$ as detailed under Methods. Values represent mean percentage cytotoxicity \pm SD for each experiment. A total of 7 controls and 14 IDA samples were examined in four separate experiments with triplicate determinations. Each experiment employed 2 to 4 IDA and 1 to 2 control samples.

' Only one control was employed in this experiment and values represent mean \pm SD of triplicate determinations of that sample.

"Statistical values were determined by a 2-way analysis of variance using an $F$ test to account for the day to day experimental variations of cytotoxicity.

For example, control lymphocytes demonstrated 29.3 and $25.7 \%$ LDCC compared to significantly decreased cytotoxicity $15.7 \%(P<0.01)$ and $15.9 \%(P<$ 0.05 ), shown by IDA lymphocytes at 1 and $2.5 \mu \mathrm{g} / \mathrm{ml}$ concentrations of PHA. respectively.

We investigated whether human leukocyte interferon- $\alpha$ or interleukin 2 could activate or restore the depressed cytotoxicity of IDA lymphocytes against K562 target cells. Data presented in Fig. 1 demonstrate that control PBL precultured with either IFN- $\alpha$ or IL-2 show significant enhancement of their NK activity, i.e., 58.4\% $(P<0.01)$ and $68.3 \%(P<0.007)$, respectively, compared to $42.5 \%$ cytotoxicity shown by untreated control cultures. Patient groups were separated into "moderate" and "reduced" NK activity. The former represents cytotoxic activity within 2 standard deviations (SD) below the mean for controls whereas the latter includes all individuals whose NK activity was less than 2 SD below the mean control value. IDA lymphocytes which demonstrated only slightly decreased or moderate NK activity $(34.2 \%)$ compared to control lymphocytes $(42.5 \%)$ displayed a significant enhancement of their NK activity when treated with either IFN- $\alpha(46.8 \% ; P<0.01)$ or IL-2 $(50.0 \% ; P<0.01)$ in comparison to untreated control cultures (34.2\%). PBL from IDA patients which showed highly depressed NK activity (20.0\%) also manifested significant enhancement of their cytotoxic potential when incubated with IFN- $\alpha(34.0 \% ; P<0.01)$ or IL-2 $(52.4 \%$; $P<0.001$ ). The percentage enhancement of both IFN- $\alpha$ and IL-2-induced cy- 
TABLE 2

aDCC activity of Lymphocytes from Healthy Donors and Intrayenous Drug Abusers at Varying EfFector to Target Cell Ratios ${ }^{a}$

\begin{tabular}{|c|c|c|c|c|c|}
\hline \multirow[b]{2}{*}{ Expt } & \multirow[b]{2}{*}{$\begin{array}{l}\text { Lymphocyte } \\
\text { source }\end{array}$} & \multicolumn{4}{|c|}{$\mathrm{E}: \mathrm{T}$ cell ratios } \\
\hline & & $100: 1$ & $\begin{array}{l}50: 1 \\
\quad \text { cytoto }\end{array}$ & $(\%)^{25: 1}$ & $5: 1$ \\
\hline 1 & $\begin{array}{l}\text { Controls } \\
\text { IDA }\end{array}$ & $\begin{array}{l}38.2 \pm 8.2 \\
21.1 \pm 10.8\end{array}$ & $\begin{array}{l}36.7 \pm 6.7 \\
19.6 \pm 7.6\end{array}$ & $\begin{array}{l}23.8 \pm 3.4 \\
13.9 \pm 5.6\end{array}$ & $\begin{aligned} 10.8 & \pm 1.8 \\
6.8 & \pm 2.0\end{aligned}$ \\
\hline 2 & $\begin{array}{l}\text { Controls } \\
\text { IDA }\end{array}$ & $\begin{array}{l}51.2 \pm 6.2 \\
24.9 \pm 3.0\end{array}$ & $\begin{array}{l}47.2 \pm 7.1 \\
21.3 \pm 2.1\end{array}$ & $\begin{array}{l}29.2 \pm 5.6 \\
10.7 \pm 2.3\end{array}$ & $\begin{array}{l}24.2 \pm 4.1 \\
11.0 \pm 9.4\end{array}$ \\
\hline 3 & $\begin{array}{l}\text { Controls } \\
\text { IDA }\end{array}$ & $\begin{array}{l}49.2 \pm 3.7 \\
32.0 \pm 10.9\end{array}$ & $\begin{array}{l}45.2 \pm 4.8 \\
29.0 \pm 11.1\end{array}$ & $\begin{array}{l}32.1 \pm 3.4 \\
12.0 \pm 3.8\end{array}$ & $\begin{array}{r}18.2 \pm 1.8 \\
8.3 \pm 4.5\end{array}$ \\
\hline 4 & $\begin{array}{l}\text { Controls }{ }^{b} \\
\text { IDA }\end{array}$ & $\begin{array}{l}51.4 \pm 4.8 \\
20.6 \pm 1.2\end{array}$ & $\begin{array}{l}47.6 \pm 5.6 \\
17.7 \pm 5.3\end{array}$ & $\begin{aligned} 28.7 & \pm 4.2 \\
9.3 & \pm 2.1\end{aligned}$ & $\begin{array}{r}17.2 \pm 1.9 \\
5.8 \pm 0.6\end{array}$ \\
\hline & & $P<0.005^{c}$ & $P<0.01$ & $P<0.006$ & $P<0.02$ \\
\hline
\end{tabular}

"Effector cells were depleted of phagocytic cells by passage through a G-10 column and SB target cells were labeled with ${ }^{51} \mathrm{Cr}$ as detailed under Methods. Values represent mean percentage cytotoxicity \pm SD in each experiment. A total of 7 controls and 14 IDA samples were examined in four separate experiments with triplicate determinations. Each experiment employed 2 to 4 IDA and 1 to 2 control samples.

${ }^{b}$ Only one control was employed in this experiment and values represent mean \pm SD of triplicate determinations.

'Statistical values were determined by a 2-way analysis of variance using $F$ test to account for the day to day experimental variation of cytotoxicity.

totoxicity (136 and $147 \%$, respectively) of IDA lymphocytes which demonstrated moderate NK activity was comparable with IFN- $\alpha$ (137\%)- and IL-2 (160\%)induced enhancement of control PBL. IDA lymphocytes which showed very reduced NK activity demonstrated greater percentage enhancement of IFN- $\alpha$ $(170 \%)$ - and IL-2 (262\%)-induced cytotoxicity compared to enhancement of either

TABLE 3

Effect of Lectin on Cellular Cytotoxicity of IDA Lymphocytes ${ }^{a}$

\begin{tabular}{lcccc} 
& \multicolumn{4}{c}{ PHA-P concentrations $(\mu \mathrm{g} / \mathrm{ml})$} \\
\cline { 2 - 5 } $\begin{array}{c}\text { Lymphocyte } \\
\text { Source }\end{array}$ & 0 & \multicolumn{2}{c}{$\%$} & 2.5 \\
\hline Controls & $4.2 \pm 1.8^{c}$ & $29.3 \pm 4.5$ & $25.7 \pm 3.8$ & $19.7 \pm 3.1$ \\
& & $(P<0.005)^{d}$ & $(P<0.005)$ & $(P<0.005)$ \\
IDA & $3.0 \pm 0.9$ & $15.7 \pm 2.3$ & $15.9 \pm 3.7$ & $14.0 \pm 4.9$ \\
& & $(P<0.005)$ & $(P<0.01)$ & $(P<0.05)$ \\
\hline
\end{tabular}

"The lectin-dependent cellular cytotoxicity (LDCC) assay was carried out similar to the NK assay except the NK resistant $\mathbf{S B}$ cell line was used as targets as described under Methods.

${ }^{b}$ Percentage cytotoxicity was calculated as described under Methods.

c Values represent mean percentage cytotoxicity \pm SD of three separate experiments performed in a single day to avoid experimental variation employing three normal controls and three patients. Experiments were performed in triplicate at a 50:1 effector to target cell ratio.

${ }^{d}$ Statistical values were determined by 2 -sample $t$ tests on differential scales. 


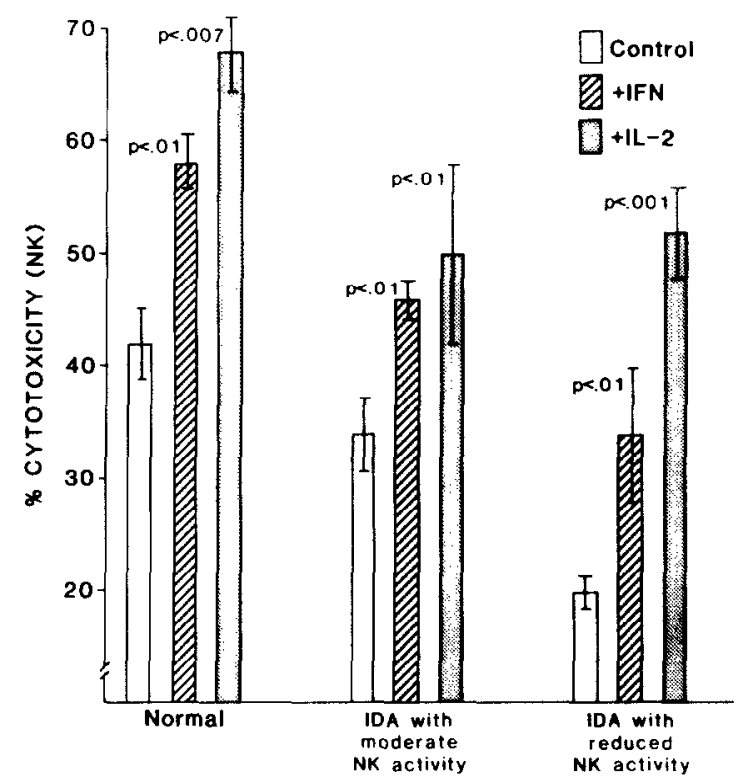

FIG. 1. Effect of IFN and IL-2 on NK activity. PBL depleted of adherent cells were precultured with IFN $(500 \mathrm{U})$ or $1 \mathrm{~L}-2(10 \% \mathrm{~V} / \mathrm{V}$, previously found to yield maximal $\mathrm{NK}$ augmenting effect. for $24 \mathrm{hr}$ at $37^{\circ} \mathrm{C}$. washed and tested for NK activity against prelabeled $\mathrm{K} 562$ target cells at a $50: \mathrm{I}$ effector to target cell ratio. Patient groups were separated into "moderate" and "reduced" NK activity. The former represents cytotoxic activity within 2 standard deviations below the mean for controls whereas the latter includes all individuals whose NK activity was less than 2 SD below the mean control value. The viability of lymphocytes precultured with either IFN or IL-2 wis comparable with that of control cultures and was found to be $>85 \%$ as assessed by vital dye exclusion. Results are expressed as mean percentage cytotoxicity $\pm \mathrm{SD}$ of four separate experiments performed in triplicate. Each experiment included one patient and one control. The statistical significance of differences in mean values was determined using a paired $t$ test formula.

IDA lymphocytes with moderately reduced NK activity $(136$ and $147 \%$, respectively, for IFN- $\alpha$ and IL-2) or control lymphocytes $(137$ and $160 \%$, respectively. for IFN- $\alpha$ and IL-2). Thus, although the cytotoxicity could not be restored completely to normal levels, the percentage enhancement of cytotoxicity by IFN- $\alpha$ or IL-2 was remarkably higher in IDA patients with highly depressed cytotoxic functions.

Studies by ourselves (28) as well as others (29) demonstrated that normal sera contains suppressive factors directed against $\mathrm{NK}$ and $\mathrm{ADCC}$ functions of normal autologous and allogeneic lymphocytes, and these factors are significantly higher in sera from a variety of cancer patients. We investigated the ability of IDA sera for their suppressive effect on NK and ADCC activities of allogeneic lymphocytes from control donors. The data presented in Fig. 2, show that allogeneic normal lymphocytes precultured with normal human sera produce $41.5 \%$ NK activity compared to significantly decreased cytotoxicity $(23.2 \% ; P<0.05)$ shown by the same lymphocytes precultured with IDA sera. In the ADCC assay, allogeneic lymphocytes precultured with normal human sera demonstrated $31.6 \%$ cytotoxicity compared to significantly reduced cytotoxicity $(10.5 \% ; P<0.01)$ displayed 


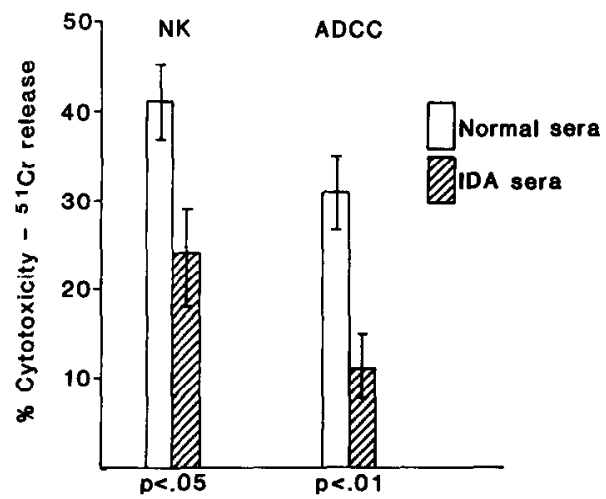

FIG. 2. Inhibition of NK and ADCC activities of allogeneic normal PBL by control and IDA sera. All sera were heat treated at $56^{\circ} \mathrm{C}$ for $1 \mathrm{hr}$ and tested at a $10 \%(\mathrm{~V} / \mathrm{V})$ final concentration in the assay. A total of five individual sera were examined separately in each group in a single day to avoid experimental variation. Mean percentage inhibition \pm SD is presented. The experiments were done in triplicate at a 50:1 effector to target cell ratio. The statistical significance of differences in mean values was determined using a paired $t$ test formula.

by lymphocytes precultured with IDA sera. All IDA serum samples tested demonstrated some inhibition ranging from 15 to $52 \%$.

Experiments were carried out to investigate whether circulating serum IFN was responsible for the suppressed NK and ADCC activity observed in IDA patients. Circulating serum IFN levels in controls as well as IDA patients were negligible except one patient who demonstrated a significantly increased level of IFN $(1760 \mathrm{U} / \mathrm{ml})$ (data not presented). Interestingly, PBL from this patient showed moderate levels of NK activity (32\%) and his lymphocytes failed to demonstrate significant enhancement (38\% cytotoxicity, 18\% enhancement) of NK activity when pretreated with IFN- $\alpha$ in vitro (data not presented). This latter observation suggests that endogenous serum IFN levels may modulate NK activity in vivo and in certain patients, elevated IFN levels may make their PBL resistant to further enhancement of NK activity with exogenous IFN.

\section{DISCUSSION}

Recent evidence suggests that NK cells represent a first line of defense against spontaneously developing neoplasms $(26,30-35)$. Patients with cancer and AIDS exhibit significantly lower levels of NK activities than control donors, potentially predisposing them to progressive disease. Many reports suggest that parenteral drug abusers are at an increased risk of developing AIDS and other immunologic abnormalities have also been observed in patients with narcotic addiction $(5,6$, $12,14-16,18-22,24)$. We report herein that lymphocytes from intravenous drug abusers display significantly decreased NK and ADCC activities against K562 and SB target cells, respectively, compared to age- and sex-matched healthy controls. Because of the indiscriminate and extensive use of several drugs in a variety of ways, the effect seen in these patients cannot be correlated with any particular substance. The reduced NK and ADCC activities observed in IDA 
patients are consistent with reports demonstrating similar findings in AIDS patients (13).

NK cells appear to have some selectivity since certain targets are very susceptible whereas others are resistant. This may be duc to differences in the antigenic structures present on target cells or the receptor sites on NK cells or both. It has been demonstrated that lymphocyte cytotoxicity can be activated by lectin (PHA). The exact mechanism of lectin activation is not presently understood, but it has been suggested that it may act directly on cytotoxic cells by rearranging cryptic receptors for recognition sites on target cells, providing sufficient signals to trigger subsequent lytic events $(37,38)$. In the present report it was demonstrated that the cytotoxicity of IDA lymphocytes could be considerably enhanced by PHA even though cytotoxicity could not be restored to normal levels (Table 3).

Sera from cancer patients appear to contain factors capable of inhibiting NK and ADCC reactions $(28,29)$. Analysis of serum factors that can inhibit NK and ADCC activities may thus be relevant to host resistance to tumor growth. Recently several reports demonstrated that sera from AIDS patients blocked normal lymphocyte responses and IFN-induced NK activity $(8.30 .31)$. In the present investigation sera from IDA patients showed significant inhibitory effects on NK and ADCC functions of control lymphocytes compared to normal sera (Fig. 2). This suppressive effect of IDA sera was not due to altered target susceptibility since the viability of target cells pretreated with IDA sera was comparable to that of targets pretreated with control sera (data not presented). Further the effect was due not to dilution, since identical aliquots of normal human sera were always: used as control. The suppressive activity of IDA sera showed a dose-dependent effect. When two different IDA serum samples were tested at 1,5 . and $10 \%$ (vol $/$ vol) final concentration in $10 \%$ fetal calf serum. they exhibited proportionally greater suppression of cytotoxicity with increasing concentration compared to normal donor serum (data not shown). Thus, immunodeficiency in IDA may be associated with the development of soluble serum suppressor factors. The ability of IDA serum to inhibit the NK and ADCC activities of lymphocytes in vitro may reflect similar inhibitory effects on NK and ADCC effector cells in vivo. Increase in soluble inhibitory activity in the sera of IDA patients may predispose them to various infections and possibly to malignancy.

IFN has been used as a stimulator of NK cell activity in viro and in vitro. The mechanism of NK activation by IFN remains to be determined. IFN may activate noncytotoxic pre-NK cells to mature cytotoxic effector cells $(38-40)$ or activate mature NK cells that are transiently inactive or potentiate endogenous lytic mechanisms by developing new receptors or modulating preexisting cell surface molecules or their avidity (39-42). However, it has been suggested that IFN may be particularly effective in patients with a sufficient number of target specific precursors of natural killer cells $(38,43,44)$. Rook et al. (13) demonstrated that IFN could not activate the cytotoxic potential of lymphocytes from AIDS patients but this activity could be enhanced with IL-2. Recently Reddy and co-workers (45) also demonstrated that NK activity could be enhanced with IL-2 in homosexual men with AIDS. Krown and her associates (46) have demonstrated that recom- 
binant human leukocyte IFN was capable of inducing tumor regression in patients with Kaposi's sarcoma. DeStefano et al. (47) showed the presence of an acidlabile IFN in AIDS patients' sera which may be responsible for the lack of NK cell responsiveness to exogenous IFN.

A number of mechanisms may be involved in the IL-2-induced enhancement of NK activity, including the ability of IL-2 to expand the immunoreactive helper and effector clones of NK cells, induce more target recognition structures on NK cells, activate precursor cytotoxic cells, increase the production of natural killer cytotoxic factor and/or hasten the recycling phase of the effector cells. Others have shown that NK cells are themselves capable of secreting IFN (48) and a critical role of IL-2 in the production of IFN has been proposed $(49,50)$. Therefore it is conceivable that IL-2 may stimulate production of IFN, which alone or synergistically with IL-2, may subsequently enhance the NK activity of lymphocytes. Watson et al. (51) proposed that IL-2 could replace helper cell functions and therefore was important in cytotoxic mechanisms. The present investigation demonstrates that both NK and ADCC activities of lymphocytes from IDA patients are depressed, but these activities could be significantly enhanced by treatment with IFN and IL-2 (Fig. 1). The degree of augmentation of NK activity with IFN and IL-2 was particularly higher in IDA patients who displayed the lowest endogenous NK activities. The increased cytotoxicity of IDA lymphocytes induced by PHA, IFN, and IL-2 also suggests that LDCC precursors and lymphokine-responsive NK precursors were normal, while active NK effectors may have been deficient in IDA patients. Further studies employing single cell assays with Percoll-enriched effector cells to examine target binding and the post binding phases of NK cell activity, the maximum recycling capacity to lyse target cells, and the production of natural killer cytotoxic factor, IFN, and IL-2 by IDA lymphocytes will help to delineate the cytotoxic dysfunctions in IDA patients. The sera of five of six IDA patients demonstrated negligible levels of circulating IFN suggesting that exogenous IFN could possibly potentiate the lytic capacity of patients' PBL comparable to normal lymphocytes. Therefore immunomodulation with IFN or IL-2 may hold promise for developing a unique immunotherapeutic approach to the management of the complications of IDA.

\section{ACKNOWLEDGMENTS}

We express our appreciation to Lynette McCurry for her technical assistance and Denise DuPrie for her excellent secietarial assistance.

\section{REFERENCES}

1. Siegal, F. P., Lopez, C., Hammer, G. S., Brown, A. E., Kornfeld, S. J., and Gold, J., N. Engl. J. Med. 305, 1439, 1981 .

2. Masur, H., Michelis, M. A., Green, J. B., et al., N. Engl. J. Med. 305, 1431, 1981.

3. Gottlieb, M. S., Schroff, R., Schanker, H. M., Weisman, J. D., Fan, P. T., Woll, R. A., and Saxon, A., N. Engl. J. Med. 305, 1426, 1981.

4. Gallo, R. C., Sarin, P. S., Gelmann, E. P., et al., Science (Washington, D.C.). 220, 865, 1983.

5. Gold, K. D., Thomas, L., and Garrett, T. J., N. Engl. J. Med. 307, 498, 1982.

6. Mol, B., Emeson. E. E., and Small C., Clin. Immunol. Immunopathol. 25, 417, 1982.

7. Barre-Sinoussi, F., Chermann, J. C., Rey, F. et al., Science (Washington, D.C.) 220, 868. 1983.

8. Cunningham-Rundles, S., Michelis, M. A., and Masur, H., I. Clin. Immunol. 3, 156, 1983.

9. deShazo, R. D., Andes, W. A., Nordberg, J., Newton, J., Daul. C., and Bozelka, B., Ann. Intern. Med. 99, 159. 1983. 
10. Essex, M., McLane. M. E., Lee, T. H. et al., Science (Washington. D.C.) 220, 859, 1983.

11. Lane. H. C.. Masur. H.. Whalen, G., Rock. A. H.. and Fauci. A. S., N. Engl. J. Med. 309, 453. 1983.

12. Laurence, J., Gottlieb. A. B., and Kunkel, H. G., J. Clin. Invest. 72, 2072. 1983.

13. Rook. A. H.. Masur, H., Lane, H. C. et al., J. Clin. Imest. 72, 298.1983.

14. Rubinstein, A., Sicklick, M., Gupta, A., et al., JAMA 249, $2350,1983$.

15. Stahl, R. E., Friedman-Kien. A.. Dubin. R., Marmor, M.. and Zolla-Pasner, S., Amer. J. Med. $73,171,1982$.

16. Centers for Disease Control's Task Force on Acquired Immune Deficiency Syndromes. U.S. Morbid. Mortal. Weckly Rep. 32, 30, 1983.

17. Kornfeld, H., VandeStouwe, R. A.. Lange. M., Reddy, M. M.. and Grieco. M. W., N. Eng/. I. Med. 307, 729, 1982.

18. Harris. P. D., and Garret, R., N. Engl. J. Med. 287, 310. 1972.

19. Helpern, M., and Rho, Y. M. N.Y. State J. Med. 66, 2391, 1966.

20. Brown. S. M., Stimmel, B., Taub. R. N., Kochwa. S., and Rosenfield, R. E., Arch. Inlern. Mad. 134, 1001. 1974.

21. Nahas. G. G.. Suciu-Foca. N., Armand. J. P., and Morishima. A., Science (Washington, D.C.) $183,419,1974$.

22. Gupta. S., Grieco, M. H., and Cushman, Jr., P. N. Engl. J. Med. 291. 874. 1974.

23. Goedort, J. J., Neuland, C.. Wallen, W. C.. ct al., Lancet 1, 412. 1982.

24. Husby, G.. Pierce. P. E., and Williams, R. C.. Ann. Intem. Med. 83, 801. 1975.

25. Boyum. A., J. Clin. Lah. Invest. 21(Suppl. 971, 77. 1968.

26. Nair, M. P. N.. and Schwartz. S. A., J. Immund. 126, 2221, 1981.

27. Nair. M. P. N., and Schwartz, S. A., J. Immunol. 129, $2511,1982$.

28. Nair, M. P. N., and Schwartz, S. A., Fed. Proc. 49, 1045, 1981 (abstract).

29. Holmes, E. E., Sibbitt, W. L., and Bankhurst, A. D., Clin. Res, 32, 39A, 1984 (abstract).

30. Schroff, R. W.. Gottilieb, M. S., Prince, H. E., Chai, L. L.. and Fahey. J. L.. Clin. Intmunt. Immunopathol. 27, 300, 1983.

31. Henning, A. K.. and Tomar, R. H., Clin. Inumunol. Immunopathol. 33, 258. 1984.

32. O"Toole, C. Stejskal. V., Perlmann, P. and Karlsson. M. J. Exp. Med. 139, 457, 1974.

33. Herberman, R. B. and Holden, T.. In Advances in Cancer Research (Klein, G. and Weinhouse. S., Eds.), Vol. 27. p. 305. Academic Press, 1978.

34. Cudkowicz, G., and Hochman. P. S., Immunol. Rev. 44, 13. 1979.

35. Nair. M. P. N. Schwartz, S. A. Fernandes. G., Pahwa. R., Ikehara, S. and Good. R. A. C Cll. Imunthol. 58, 9. 1981

36. Brunda. M., Varesio. L.., Herberman, R. B.. and Holden. H. T., Int. J. Cancer 29, 299.1982.

37. Spits, H.. Borst. J.. Terhorst, C., and DeVris. J. E.. I. Immunol. 129, 1563. 1982.

38. Herberman. R. R. Ortaldo. J. R., and Bonnard. G. D., Nature (London) 277, 221, 1979.

39. Saksela. E., Timonen. T.. and Cantell. K.. Scand. J. Immunol. 10, 257. 1979.

40. Bishop. (i. A., and Schwartz. S. A.. Clin. Immumol. Immumopathol. 25, 374, 1982.

41. Ortaldo. J. R.. Pestka. S., Slease, R. B.. Rubinstein. M. 1.. and Herberman. R. B.. Sicand. J. Immunol. 12, 365. 1980.

42. Gustafsson. A., and Lundgren, E.. Cell. Intmunol. 62, 367, 1981.

43. Silva. A., Bonavida. B., and Targan, S., J. Immtenol. 125, 470. 1980.

44. Toy, J. L.. Clin. Exp. Immunol. 54, 1, 1983.

45. Reddy, M. M.. Pinyavat. N., and Grieco, M. H., Infec. Immunol. 44, 339. 1984.

46. Krown. S. E., Real. F. X., Cunningham-Rundles, S. et al., N. Engl. J. Med. 308, 107l, 1983

47. DeStefano, E., Friedman, R. M., Friedman-Kien. A. E.. et al., J. Infec. Dis, 146, 451, 1982.

48. Saksela, F. T. Timonen, T., and Cantell, K., Ann N. Y. Acad. Sci. 350, 102, 1980.

49. Kasahara, T.. Hooks. J. J. Dougherty. S. F. and Oppenheim, J. J.. J. Immunol. 130, 1784. 1983.

50. Kawase, I. Brooks. G. G., Kuribayashi, K., Dabuenaga, S., Newman. W., Gillis. S., and Henney, C. S. J. Immunol. 131, 288, 1983.

51. Watson, J., Aarden, L. A.. Shaw, J., and Paetkau, V., J. Immunol. 122, 1633, 1979.

Received March 15. 1985: accepted with revision June 27. 1985 